\title{
Effect of Sublethal Dose of Dichlorvos on the Biochemical Parameters of African Catfish
}

\author{
Cosmas Ezekaibeya Achikanu and Onuabuchi Nnenna Ani* \\ Department of Applied Biochemistry, Faculty of Applied Natural Sciences, Enugu State University of Science and Technology, Enugu, Nigeria
}

*Corresponding author: Onuabuchi Nnenna Ani, Department of Applied Biochemistry, Faculty of Applied Natural Sciences, Enugu State University of Science and Technology, Enugu, Nigeria; E-mail: nnenna.ani@esut.edu.ng

Received: 15 Apr, 2021 | Accepted: 30 Apr, 2021 | Published: 07 May, 2021

Citation: Achikanu CE, Ani ON (2021) Effect of Sublethal Dose of Dichlorvos on the Biochemical Parameters of African Catfish. J Biochem Analyt Stud 5(1): dx.doi.org/10.16966/2576-5833.125

Copyright: (C) 2021 Achikanu CE, et al. This is an open-access article distributed under the terms of the Creative Commons Attribution License, which permits unrestricted use, distribution, and reproduction in any medium, provided the original author and source are credited.

\begin{abstract}
The present study investigated the effects of sublethal concentrations of dichlorvos on liver marker enzymes (aspartate aminotransferase, alanine aminotransferase and alkaline phosphatase), acid phosphatase (ACP), serum total protein (STP), bilirubin, urea and creatinine in African Catfish (Clarias gariepinus) juveniles at sub acute period under laboratory conditions. A total of 90 juveniles of Clarias gariepinus with average weight and length of $200.15 \pm 0.09 \mathrm{~g}$ and $26.00 \pm 0.00 \mathrm{~cm}$ respectively were kept in three experimental groups of 30 per group in triplicate of 10 fishes. Groups 1 and 2 were exposed to dichlorvos at dosages of 21 and $43 \mathrm{mg} / \mathrm{l}$ respectively and group 3 served as control for 15 experimental days. Analyses were carried out on days 1, 5, 10 and 15. From the results, there was no significant changes in the biochemical parameters tested on day 1 of the experiment but levels of the liver enzymes, ACP and bilirubin increased significantly $(p<0.05)$ on other experimental days when compared with the control group. However, there was insignificant increase in the urea level and also a non-significant decrease in the creatinine and Serum total protein (STP) levels of the experimental groups when compared with the control group. From the analyses and observations made, we conclude that the administration of sublethal concentrations of dichlorvos to African catfish induced some damages to the liver which affected the levels of the liver enzymes and the increase in ACP level is indicative of carcinogenicity.
\end{abstract}

Keywords: Dichlorvos; African catfish; Clarias gariepinus; Acid phosphatase; ALT; AST; Protein; Bilirubin; ALP; Biochemical parameters; Liver; Enzymes

\section{Introduction}

Pollutants and toxic discharges from processes in industries, mining, and agriculture find their way into the aquatic environment. This may have adverse effects on aquatic lives. One of such pollutants is pesticides which cause great harm to the animals present in the aquatic environment including fishes [1]. A large amount of these pesticides reach aquatic ecosystem through various routes such as direct application, spray-drift, run-off, leaching, discharge from factories and sewage, and all these have negative health impacts on different non-target aquatic organisms [2,3]. Dichlorvos (2,2-dichlorovinyl dimethyl phosphate; DDVP), an organophosphate insecticide is widely used in agriculture and in control of household pests in public health, and protecting stored products from insects. It is also used as an anti-helminthic for dogs, swine, and horses, as a botacide; agent that kills fly larvae [4]. They act by interfering with the activities of cholinesterase, an enzyme that is essential for the proper functioning of the nervous systems of humans and insects. Exposure to an organophosphate such as dichlorvos could be lethal and cause death from respiratory failure [5].
Recent works done on the effects of dichlorvos on various aspects of the fish are those of Nwamba HO, et al., [6]. They reported the impact of dichlorvos on African catfish and pointed out a strong evidence of stress responses characterised by hyperactive swimming with subsequent erratic jerky movements before death. In another report, dichlorvos was found to induce oxidative stress that may overwhelm the antioxidant system of juvenile catfish especially at higher concentrations with long exposure. The effects of dichlorvos on the liver of poultry birds was also reported [7]. Therefore, it is imperative to find out the biochemical effects of this pesticide on fish as they forman important link in food chain and their contamination by pesticides causes imbalance in the aquatic system. Fish form a part of diet for both humans and animals being an important source of protein. African catfish in particular is a common delicacy by locals in African countries. In general, fishes are severely affected by pesticides which mostly affect their vital organs such as the kidney and liver. The kidney plays an important role in the maintenance of internal environment of an organism. It regulates the volume and composition of extracellular fluid including the acid-base balance. The toxic chemicals target the kidney and disrupt its functions causing temporary or permanent derangement of homeostasis [8]. 
The liver is involved in digestion, absorption and procession of food. It also plays a vital role in detoxification of chemicals, drug metabolism and secretion of bile into the intestines. When these toxic chemicals get to the liver, they can overwhelm it and impair its function which can shut down the system leading to death. In this study, the effects of exposure of sub-lethal dose of dichlorvos on African catfish were examined by finding out the changes in the biochemical indices and activities of marker enzymes.

\section{Materials and Method}

\section{Procurement of experimental fish and acclimatization}

A total of 90 juveniles of Clarias gariepinus (African catfish) were obtained from CJ agro fish farm located at New Haven Enugu, Nigeria. They were transported to Heidin's fishery unit, Emene, Enugu, Nigeria. They had average weight and length of $200.15 \pm 0.09 \mathrm{~g}$ and $26.00 \pm$ $0.00 \mathrm{~cm}$ respectively. The fishes were acclimatized for two weeks under laboratory conditions prior to tests in semi-static system. They were fed with commercially available Coppens fish meal daily at $3 \%$ body weight. Water $\left(24^{\circ} \mathrm{C}\right.$ temperature and $\mathrm{pH}$ of 7.5$)$ was changed daily to remove feacal matter and other waste materials. Feeding was stopped $48 \mathrm{hrs}$ before the commencement of the experiment and they were not fed throughout the experimental period.

\section{Test pesticides}

The pesticide; dichlorvos was procured from a commercial outlet in Ogbete market Enugu, Nigeria.

Experimental design: The study was carried out for a period of 15 days. The fishes were kept in a container of 10 litres of fresh water in the laboratory at water temperature and $\mathrm{pH}$ of $24^{\circ} \mathrm{C}$ and 7.50 respectively. They were kept in two experimental groups (2 and 3) of 30 per group in triplicate of 10 fishes each. Group 1 served as control without treatment. Groups 2 and 3 were treated with dichlorvos at concentrations of 21 and $43 \mathrm{mg} / \mathrm{l}$ respectively. Each concentration was replicated three times. Feeding was stopped $48 \mathrm{hrs}$ before the commencement of the experiment. Three active juveniles were randomly harvested from each group at five days interval (day 1, 5, 10, 15), sacrificed and blood drawn with a $2 \mathrm{ml}$ syringe from the caudal vein for biochemical analysis.

\section{Biochemical assay}

Aspartate aminotransferase (AST) and alanine aminotransferase (ALT) were determined according to the method of Reitman S and Frankel S [9] while alkaline phosphatase (ALP) was determined according to the method of Babson AL, et al., [10] as outlined in Randox diagnostic kits. Acid phosphatase (ACP) activity, Urea, Creatinine and serum total protein levels were determined according to the method of Tietz NM, et al., [11] as outlined in Randox kit. Total bilirubin was determined according to Jendrassik-Grof analysis for total and direct bilirubin [12].

\section{Statistical analysis}

Analysis of data was carried out using SPSS version 7 statistical packages. Statistical significance of the results between groups was determined using one way analysis of variance (ANOVA). Differences between means were considered significant at $\mathrm{P}<0.05$.

\section{Results}

The mean effect of dichlorvos pesticides on the catfish for day 1 in comparison with the control is shown in table 1 . There was no
Table 1: Mean effect of dichlorvos pesticide on the catfish (Clarias gariepinus) juveniles on day 1.

\begin{tabular}{|c|c|c|c|}
\hline Parameter & $21 \mathrm{mg} / \mathrm{I}$ & $43 \mathrm{mg} / \mathrm{l}$ & Control \\
\hline AST & $48.00 \pm 1.00$ & $42.33 \pm 0.58$ & $44.00 \pm 1.00$ \\
\hline ALP & $60.33 \pm 2.52$ & $60.00 \pm 1.00$ & $61.00 \pm 1.00$ \\
\hline ALT & $30.67 \pm 3.06$ & $30.00 \pm 1.00$ & $33.00 \pm 2.00$ \\
\hline ACP & $81.33 \pm 2.08$ & $86.33 \pm 1.53$ & $81.00 \pm 1.00$ \\
\hline STP & $4.33 \pm 0.02$ & $4.19 \pm 0.01$ & $6.28 \pm 0.01$ \\
\hline BILIRUBIN & $0.66 \pm 0.02$ & $0.56 \pm 0.015$ & $0.54 \pm 0.01$ \\
\hline CREATINENE & $4.29 \pm 0.02$ & $4.43 \pm 0.02$ & $4.34 \pm 0.01$ \\
\hline UREA & $68.33 \pm 0.58$ & $65.33 \pm 2.08$ & $62.67 \pm 0.58$ \\
\hline
\end{tabular}

significant changes $(\mathrm{p}<0.05)$ in the biochemical parameters tested on day 1 following exposure of the fishes to dichlorvos.

The mean effect of dichlorvos pesticides on the catfish (Clarias gariepinus) juveniles for day 5 in comparison with the control is shown in table 2 . There was significant increase $(\mathrm{p}<0.05)$ in the levels of the liver enzymes, ACP and bilirubin of the experimental groups (21 and $43 \mathrm{mg} / \mathrm{l}$ ) and non-significant increase in the urea level when compared with the control. STP and creatinine levels were reduced non-significantly.

The mean effect of dichlorvos pesticides on the catfish (Clarias gariepinus) juveniles for day 10 in comparison with the control is shown in table 3 . There was significant increase $(p<0.05)$ in the levels of the liver enzymes and ACP with non-significant increase in the bilirubin and urea levels of the experimental groups when compared with the control group. The creatinine level was reduced nonsignificantly $(\mathrm{p}<0.05)$.

The mean effect of dichlorvos pesticides on the catfish (Clarias gariepinus) juveniles for day 15 in comparison with the control is shown in table 4 . The levels of AST, ALP and ACP were significantly increased $(p<0.05)$ in the experimental groups while ALT level was increased non-significantly when compared with the control. STP, bilirubin, creatinine and urea levels were reduced non-significantly $(p<0.05)$ but at concentration of $21 \mathrm{mg} / \mathrm{l}$, STP increased significantly.

\section{Discussion}

Investigation of toxicity associated with use of pesticide especially to non-target organisms such as fish is essential in order to sustain aquatic life and subsequently protect man from dangers to health arising from consumption of contaminated aquatic products. From the report of WHO [13], dichlorvos is said to be highly toxic with LC50 in the range $0.1-1 \mathrm{mg} / \mathrm{L}$ to moderately toxic with LC50 in the range 1 to $10 \mathrm{mg} / \mathrm{L}$ to fish, with a few reports indicating slight toxicity of LC50 in the range $10-100 \mathrm{mg} / \mathrm{L}$. Several researchers have studied the acute toxic effects of dichlorvos in different species of fish. Shepard [14] reported 96-h LC50values between 0.004-11.6 mg/Lof dichlorvos in fish. Nwamba HO, et al., [6] also reported 96 hLC50 in fishes of $17.21 \mathrm{mg} / \mathrm{L}$ with lower and upper confidence limits of $15.78-18.19 \mathrm{mg} /$ $\mathrm{L}$ respectively.

Biochemical parameters are routinely used as indicators of sublethal response to stress to endogenous or exogenous changes in fish. In this work, the sublethal toxic effects of dichlorvos at concentrations of $21 \mathrm{mg} / \mathrm{l}$ and $43 \mathrm{mg} / \mathrm{l}$ on some biochemical parameters of African catfish were examined for 15 days and the analyses were made at 5 -days intervals of 1, 5, 10 and 15 days. It has been reported that the toxicity of dichlorvos to organisms depends on sex, concentrations, 
Table 2: Mean effect of dichlorvos pesticide on the catfish (Clarias gariepinus) juveniles on day 5 .

\begin{tabular}{|c|c|c|c|}
\hline Parameter & $21 \mathrm{mg} / \mathrm{I}$ & $43 \mathrm{mg} / \mathrm{I}$ & Control \\
\hline AST & $77.67 \pm 1.53^{\mathrm{a}}$ & $75.00 \pm 5.00^{\mathrm{a}}$ & $40.33 \pm 2.51^{\mathrm{b}}$ \\
\hline ALP & $97.67 \pm 1.53^{\mathrm{a}}$ & $94.33 \pm 5.03^{\mathrm{a}}$ & $71.33 \pm 3.21^{b}$ \\
\hline ALT & $51.33 \pm 1.53^{a}$ & $54.67 \pm 1.53^{\mathrm{a}}$ & $30.00 \pm 1.00^{\mathrm{b}}$ \\
\hline ACP & $90.67 \pm 2.08^{a}$ & $77.33 \pm 2.08^{b}$ & $61.33 \pm 1.53^{\circ}$ \\
\hline STP & $5.56 \pm 0.02^{\mathrm{a}}$ & $5.20 \pm 0.02^{\mathrm{a}}$ & $7.02 \pm 0.02^{\mathrm{a}}$ \\
\hline BILIRUBIN & $0.63 \pm 0.02^{\mathrm{a}}$ & $0.84 \pm 0.02^{b}$ & $0.24 \pm 0.01^{c}$ \\
\hline CREATININE & $5.36 \pm 0.02^{\mathrm{a}}$ & $5.21 \pm 0.02^{\mathrm{a}}$ & $5.67 \pm 0.01^{\mathrm{a}}$ \\
\hline UREA & $61.67 \pm 1.53^{\mathrm{a}}$ & $56.67 \pm 1.53^{\mathrm{a}}$ & $52.67 \pm 1.16^{\circ}$ \\
\hline
\end{tabular}

Values in the same row marked with the same letter are not significantly different $(p<0.05)$.

Table 3: Mean effect of dichlorvos pesticide on the catfish (Clarias gariepinus) juveniles on day 10.

\begin{tabular}{|c|c|c|c|}
\hline Parameter & $21 \mathrm{mg} / \mathrm{I}$ & $43 \mathrm{mg} / \mathrm{l}$ & Control \\
\hline AST & $64.33 \pm 1.53^{\mathrm{a}}$ & $68.00 \pm 1.00^{a}$ & $40.33 \pm 1.52^{b}$ \\
\hline ALP & $82.00 \pm 1.00^{\mathrm{a}}$ & $82.00 \pm 1.00^{a}$ & $63.67 \pm 1.00^{b}$ \\
\hline ALT & $46.33 \pm 1.53^{a}$ & $44.00 \pm 1.00^{\mathrm{a}}$ & $30.33 \pm 1.53^{b}$ \\
\hline ACP & $91.00 \pm 1.00^{\mathrm{a}}$ & $94.33 \pm 2.00^{\mathrm{a}}$ & $64.00 \pm 1.00^{b}$ \\
\hline STP & $5.19 \pm 0.01^{\mathrm{a}}$ & $5.23 \pm 0.58^{\mathrm{a}}$ & $6.30 \pm 0.01^{\mathrm{a}}$ \\
\hline BILIRUBIN & $0.48 \pm 0.01^{\mathrm{a}}$ & $0.58 \pm 0.01^{\mathrm{a}}$ & $0.42 \pm 0.01^{\mathrm{a}}$ \\
\hline CREATININE & $4.57 \pm 0.01^{\mathrm{a}}$ & $4.53 \pm 0.02^{\mathrm{a}}$ & $5.28 \pm 0.02^{\mathrm{a}}$ \\
\hline UREA & $63.67 \pm 0.58^{\mathrm{a}}$ & $57.66 \pm 0.58^{a}$ & $60.33 \pm 0.58^{\mathrm{a}}$ \\
\hline
\end{tabular}

Values in the same row marked with the same letter are not significantly different $(p<0.05)$.

Table 4: Mean effect of dichlorvos pesticide on the catfish (Clarias gariepinus) juveniles on day 15.

\begin{tabular}{|l|c|c|c|}
\hline \multicolumn{1}{|c|}{ Parameter } & 21mg/I & 43mg/I & Control \\
\hline AST & $62.00 \pm 1.00^{\mathrm{a}}$ & $60.00 \pm 2.00^{\mathrm{a}}$ & $38.00 \pm 1.00^{\mathrm{b}}$ \\
\hline ALP & $74.33 \pm 0.58^{\mathrm{a}}$ & $71.00 \pm 1.00^{\mathrm{a}}$ & $61.00 \pm 1.00^{\mathrm{b}}$ \\
\hline ALT & $32.33 \pm 0.58^{\mathrm{a}}$ & $30.33 \pm 1.53^{\mathrm{a}}$ & $28.00 \pm 2.00^{\mathrm{a}}$ \\
\hline ACP & $74.00 \pm 1.00^{\mathrm{a}}$ & $70.00 \pm 1.00^{\mathrm{a}}$ & $60.00 \pm 2.00^{\mathrm{b}}$ \\
\hline STP & $14.21 \pm 0.02^{\mathrm{a}}$ & $4.15 \pm 0.02^{\mathrm{b}}$ & $5.36 \pm 0.02^{\mathrm{b}}$ \\
\hline BILIRUBIN & $0.41 \pm 0.01^{\mathrm{a}}$ & $0.52 \pm 0.01^{\mathrm{a}}$ & $0.58 \pm 0.01^{\mathrm{a}}$ \\
\hline CREATINENE & $5.35 \pm 0.02^{\mathrm{a}}$ & $5.30 \pm 0.01^{\mathrm{a}}$ & $6.92 \pm 0.01^{\mathrm{a}}$ \\
\hline UREA & $52.33 \pm 0.58^{\mathrm{a}}$ & $49.00 \pm 1.00^{\mathrm{a}}$ & $54.00 \pm 1.00^{\mathrm{a}}$ \\
\hline
\end{tabular}

Values in the same row marked with the same letter are not significantly different $(p<0.05)$.

developmental stages and exposure periods [15]. On day 1 of the experiment, there were no significant changes in the values of the liver enzymes at the two concentrations evaluated when compared with the control as shown in table 1. Liver enzymes (ALT, AST and ALP) are marker enzymes for liver function and integrity [16,17]. Liver enzymes are released into the blood during liver cells damage thereby increasing the enzyme activity $[18,19]$. Elevation of liver enzymes is also associated with cell necrosis of many tissues especially the liver [20]. From the result, the activities of transaminases were not significantly $(\mathrm{p}<0.05)$ altered on day 1 following exposure to dichlorvos. This indicates that dichlorvos did not cause immediate necrotic effect on the liver. However, there was significant increase in the activities of the liver enzymes at both concentrations on days 5 and 10 but minimally on day 15 for ALT when compared with the control.
This indicates that the damages to the liver tissues are dependent on the duration of exposure and the insignificant changes observed for ALT on day 15 could be as a result of regrowth of some of the damaged tissues overtime. Therefore, the toxic effect of dichlorvos on the liver of fish is dependent on duration of exposure and may not necessarily be attributed to dose as observed in tables 1-4. Of worthy of note is the increase in ALP level more than the other liver enzymes in all the experimental days. Alkaline phosphatase (ALP) is a membrane-bound enzyme and its elevation indicates intra- hepatic cholestasis. There was also a consequent rise in the bilirubin levels on the experimental days when compared with the normal control group. This suggests that dichlorvos induced intra-hepatic cholestasis and consequently jaundice in the experimental groups independent of the dose.

Acid phosphatases are group of lysosomal enzyme that hydrolyze phosphate at an acid $\mathrm{pH}$. They are present in many tissues such as platelets, lung, liver and kidney [21]. It has been established that acid phosphatase is a tumour marker for prostate cancer [22]. An elevation of the serum acid phosphatase level has been considered indicative of metastasizing carcinoma of the prostate [23]. In this study, there was no significant increase $(\mathrm{p}<0.05)$ in ACP level on days 1 and 15 . However, there was a significant increase $(\mathrm{p}<0.05)$ on days 5 and 10 which was not dependent on the dose when compared with the normal group. This elevation in the activity of ACP observed indicates that dichlorvos could predispose one to risk of prostate cancer following consumption of contaminated fish.

Serum total protein is a biochemical test used for measuring the total amount of protein in serum. It compares the amount of albumin with globulin which are the two classes of proteins found in the fluid portion of blood [24]. Proteins are the building blocks of tissues and cells. They are needed for growth and development. They also form the structural part of organs; make up hormones and enzymes. A change in the total protein levels could be attributed to various conditions which may cause either abnormal high production of protein, interfere with the production of albumin or globulin proteins or increase the loss or breakdown of proteins. Decrease in the serum total protein level due to toxicity could be as a result of massive hepaticnecrosis and chronic cirrhosis which significantly destroys the liver cells. From the result of the analysis, the level of serum total protein (STP) was reduced insignificantly $(\mathrm{p}<0.05)$ at the two concentrations tested on days 1,5 and 10 but significantly increased $(\mathrm{p}<0.05)$ at $21 \mathrm{mg} / 1$ on day 15 as shown in table 4 . This indicates that longer exposure to dichlorvos interfered with protein synthesis or caused loss of protein via excretion and also suggests a negative effect in the kidney and the liver. This observation could also mean that the changes in the serum total protein is dependent on the duration and may not necessarily be on the exposure dose.

Increase in blood urea is indicative of renal impairment. The most common cause of an elevated blood urea is poor kidney function, although a serum creatinine level is a more specific measure of renal function. Impaired renal excretion of urea may be due to temporary conditions such as dehydration or shock, or maybe due to either acute or chronic disease of the kidneys themselves. The exposure of $C$. gariepinus to two different doses of dichlorvos did not induce significant changes in the urea and creatinine levels. The increase observed in the urea and creatinine at $21 \mathrm{mg} / \mathrm{l}$ on days 1,5 and 10 as against the control group could be attributed to temporal conditions like dehydrations and may not be associated with damaged pancreatic cells. Creatinine is a metabolite of muscle creatinine and the amount in serum is said to be proportional to the body's muscle mass [25]. Amount of creatinine is always constant and so increased levels indicate 
reduced renal function since it is easily excreted by the kidneys [26]. From the study, creatinine level throughout the experimental days did not increase rather there was an insignificant decrease in comparison with the control group. This indicates that exposure of C. garirpinus to dichlorvos did not significantly affect the levels of creatinine.

\section{Conclusion}

Aquatic lives are at risk to environmental pollution arising especially from agricultural practices. Toxicity due to pesticides as evidenced by the sublethal doses of dichlorvos in this study is detrimental to nontarget animals such as fishes. This study showed that exposure of fishes to sub-lethal doses of dichlorvos caused various biochemical changes which are fatal to survival. Care must be taken to safeguard these aquatic lives.

\section{References}

1. Al-Otaibi AM, Al-Balawi HFA, Ahmad Z, Suliman EM (2019) Toxicity bioassay and sub-lethal effects of diazinon on blood profile and histology of liver, gills and kidney of catfish, Clarias gariepinus. Braz J Biol 79: 326-336.

2. Katagi T (2010) Bioconcentration, bioaccumulation, and metabolism of pesticides in aquatic organisms. Rev Environ Contam Toxicol 204: 1-132.

3. Sande D, Mullen J, Wetzstein M, Houston J (2011) Environmental impacts from pesticide use: a case study of soil fumigation in Florida tomato production. Int J Environ Res Public Health 8: 4649-4661.

4. USEPA:United States Environmental Protection Agency (1994) Integrated Risk Information System (IRIS) on Dichlorvos. Environmental Criteria and Assessment Office, Office of Health and Environmental Assessment, Office of Research and Development, Cincinnati, $\mathrm{OH}$.

5. Leibson T, Lifshitz M (2008) Organophosphate and Carbamate poisoning: review of the current literature and summary of clinical and laboratory experience in southern Israel. Isr Med Assoc J 10: 767-770.

6. Nwamba HO, Achikanu CE, Chukwu GP (2018). The Impact of Dichlorvos -Pesticide on African Catfish Clarias Gariepinus. Oceanogr Fish Open Access J 8: 555745.

7. Ezeji EU Onwurah INE (2017) Biochemical Effects of Dichlorvos Pesticide on the Liver of Poultry Birds (Gallus domestica). Am J Biochem 7: 23-26.

8. Miller GG, Sweet LI, Adams JV, Omann GM, Passino-Reader DR, et al. (2002) In vitro toxicity and interactions of environmental contaminants (Arochlor 1254 and mercury) and immunomodulatory agents (lipopolysaccharide and cortisol) on thymocytes from lake trout (Salvelinus namaycush). Fish Shellfish Immunol 13: 11-26.

9. Reitman S, Frankel S (1957) A colorimetric method for the determination of serum glutamic oxalacetic and glutamic pyruvic transaminases. Am J Clin Pathol Path 28: 56-63.

10. Babson AL, Greeley SJ, Coleman CM, Phillips GE (1966) Phenolphthalein mono-phosphate as a substrate for serum alkaline phosphatase. Clin Chem 12: 482-490.
11. Tietz NM (1995) Clinical Guide to Laboratory Tests. $3^{\text {rd }}$ edition, Saunders, Philadelphia, Pa, USA.

12. Garber CC (1981) Jendrassik--Grof analysis for total and direct bilirubin in serum with a centrifugal analyzer. Clin Chem 27: 14104106.

13. WHO (1989) Dichlorvos. Environmental Health Criteria 79. World Health Organization, Geneva, Switzerland.

14. Shepard TH (1986) Catalog of Teratogenic Agents. $5^{\text {th }}$ edition, Johns Hopkins University Press, Baltimore, MD: 5-10.

15. Pandey AK, Nagpure NS, Trivedi SP, Kumar R, Kushwaha B (2011) Pronfenofos induced DNA damage in freshwater fish Channa punctatus using alkaline single cell gel electrophoresis. Mutat Res 726: 209-214.

16. Adaramoye OA, Osaimoje DO, Akinsanya AM, Nneji CM, Fafunso MA, et al. (2008). Changes in antioxidant status and biochemical indices after acute administration of artemether, artemether-lumefantrine and halofantrine in rats. Basic Clin Pharmacol Toxicol 102: 412-418.

17. Ajayi GO, Adeniyi TT, Babayemi DO (2009) Hepatoprotective and some haematological effects of Allium sativum and vitamin C in lead exposed wistar rats. Int Journal Med Sci 1: 064-067.

18. Edwards CRW, Bouchier AD, Haslet C, Chilvers ER (1995) Davidson's principles and practice of Medicine, $17^{\text {th }}$ edition, Edinburgh, New York, Churchill Livingstone 24-36.

19. Effraim KD, Salami HA and Osewa TS (2000) The effect of aqueous leaf extract of Ocimum gratissium on haematological and biochemical parameters in rabbits. Afr J Biomed Res 3: 175-179.

20. Adedapo AA, Abatan MO and Olorunsogo OO (2004) Toxic effects of some plants in the genus Euphorbia on haematological and biochemical parameters of rats. Veterinarski Arhiv 74: 53-62.

21. Romas NA (1983) Prostatic acid phosphatase. Current concept. Semin Urol 1: 177-185.

22. Taira A, Merrick G, Wallner K, Dattoli M (2007) Reviving the acid phosphatase test for prostate cancer. Oncology (Williston Park) 21: 1003-1010.

23. Tuchman LR, Swick M (1957) High acid phosphatase level indicating Gaucher's disease in patient with prostatism. J Am Med Assoc 164: 2034-2035.

24. Padma P, Chansauria JPN, Khosa RL, Ray AK (2001) Effect of Annooa muricata and Polyalthia cerasoides on Brain Neurotransimitters and Enzyme Monoamine Oxidase Following Cold Immobilization Stress. Journal of Natural Remedies 1: 144-146.

25. Atangwho IJ, Ebong PE, Egbung GE, Eteng MU, Eyong EU (2007) Effect of Vernoniaamygdalina Del. on liver function in alloxaninduced hyper glycemic rats. J Pharm Biores 4: 1-7.

26. Loeb S (1991) Clinical Laboratory Test: Values and Implication. Springhouse Corporation, Springhouse, Pennsylvania. 